\title{
Impacto de la Biotecnología en la sociedad. Presente y futuro
}

\author{
Manuel Espinosa
}

\section{Introducción}

Ante la sociedad actual se nos presenta uno de los retos más apasionantes del presente siglo, únicamente comparable en la historia moderna con la revolución industrial del siglo XIX. Dos son los aspectos de este desafí, derivados ambos del desarrollo de nuevas tecnologías y que se conocen como "revoluciones" cibernética y biotecnológica. Las nuevas tecnologías en informática y comunicación, la investigación en inteligencia artificial y el desarrollo de sistemas informáticos capaces de aprendizaje y decisión, plantean una disyuntiva particular: de un lado, los niveles de comunicación e información de los individuos son mucho mayores; de otro, la posibilidad de un control exagerado sobre las personas puede ser alarmante. Por otra parte, el desarrollo de la tecnología de la Ingeniería Genética y su aplicación a problemas de alimentación y salud humana presenta un porvenir halagüeño, quizás enturbiado por la posible aplicación de esta tecnología al desarrollo de armas biológicas. La irrupción en nuestra sociedad actual de lo que se ha denominado (con no demasiado acierto) Biotecnología, no es ya un tema de futuro sino una realidad: los primeros productos de importancia terapética, derivados de la tecnología del DNA recombinante (insulina, interferón) están siendo utilizados habitualmente.

De modo necesariamente breve intentare explicar cómo ha sido posible este avance de la Biologia, plantear el estado actual y las perspectivas futuras de la Biotecnología, su impacto económico y su posible impacto social. Procuraré emplear el mínimo lenguaje científico/técnico, ya que creo deseable comunicar con claridad y precisión los descubrimientos científicos que nos han puesto a las puertas de la revolución biotecnológica.

\section{Antecedentes}

No se puede entender el desarrollo que ha experimentado la Biología sin una breve visión retrospectiva, ya que las claves de la tecnología del DNA recombinante y sus aplicaciones se encuentran en la investigación básica realizada en las pasadas décadas. El pasado año se cumplía el cincuentenario de la publicación del trabajo pionero de Fred Griffith, quien descubría la posibilidad de realizar una transformación "in vivo" de estreptococos no patógenos en formas patogénicas de la misma especie y demostraba que esta transformación era hereditaria. Quince afios más tarde, el equipo 
formado por Avery, McLeod y McCarthy descubrian que el "principio transformante" era el ácido desoxirribonucléico (DNA), pronto identificado como la molécula responsable de guardar la información necesaria para el mantenimiento de los caracteres hereditarios. Este descubrimiento despert 6 el interés por el estudio de las características del DNA, demostrándose que éste se halla formado por una larga sucesión de unidades denominadas nucleótidos. A su vez, los nucleótidos son el resultado de la combinación de un azúcar (desoxirribosa), un grupo fosfato y una de las cuatro bases que se encuentran en el DNA: adenina (A), timina (T), citosina (C) y guanina (G). En 1953 se presentó el modelo de Watson y Crick que asigna al DNA una estructura de doble hélice y en el que se postula que ambas hélices son complementarias y antiparalelas, existiendo un apareamiento de las bases (A-T y GC) de una y otra hélice (Figura 1). Las predicciones de este modelo se van confirmando experimentalmente y los descubrimientos se suceden con rapidez: se desentrafia el código genético, el cual define que cada grupo de tres bases codifica para una de las unidades (aminoácidos) que constituyen las proteínas. Así, cada gen codificaría para una proteína cuya estructura dependerá del orden (secuencia) de sus aminoácidos y ésta, a su vez, de la secuencia de nucleótidos del DNA. Se investiga el papel del ácido ribonucléico (RNA), cuyo azúcar es la ribosa y en el que la timina se halla sustituida por uracilo (U). Se realiza la primera síntesis química de un gen y se estudian los mecanismos por los que una molécula de DNA es capaz de copiarse a sí misma (replicación), mediante los enzimas DNA polimerasas. La replicación del DNA fue un descubrimiento clave para explicar la transmisión de información genética entre un ser vivo y sus descendientes. Una larga lista de nombres ilustres podrían incluirse aquí, siendo Severo Ochoa uno de ellos. Se trabaja en el análisis químico de los nucleotidos y se postula el llamado "dogma central" de la Biología (Figura 2A) que afirma que la clave genética del DNA (sucesión o secuencia de nucleótidos) se copia en el RNA mensajero (mRNA) durante el proceso de transcripción y que el mRNA se traduce en proteŕnas.

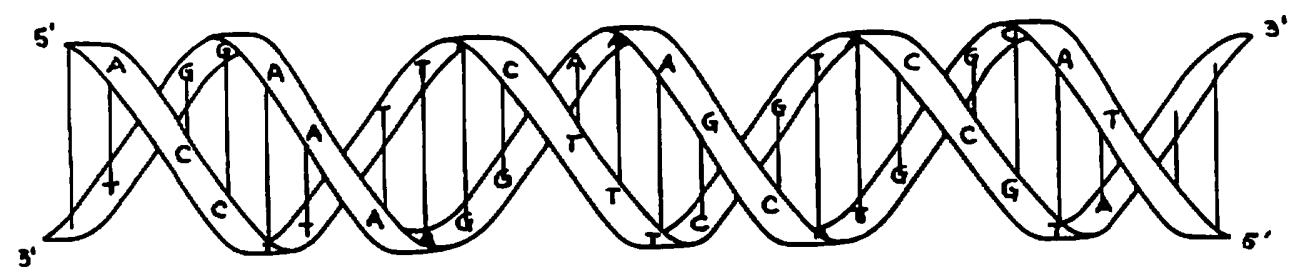

Figura 1 


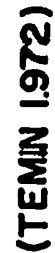

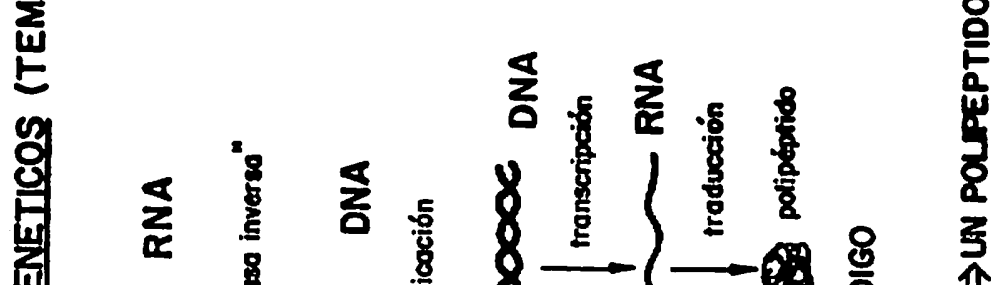

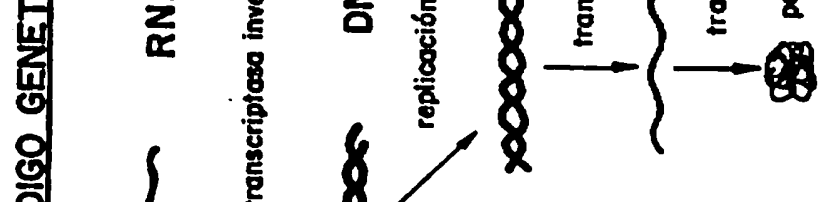

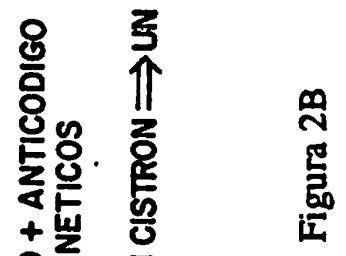

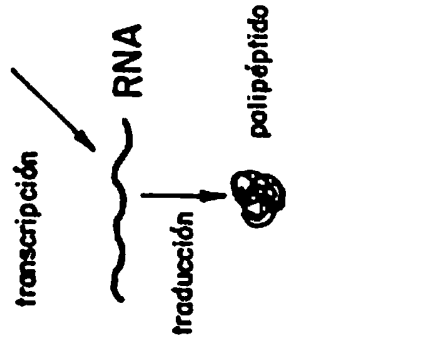

융 :

8

웜|

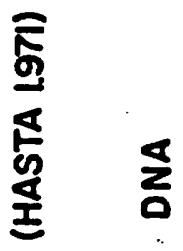

$\cdot 1 \frac{1}{\frac{5}{20}}$
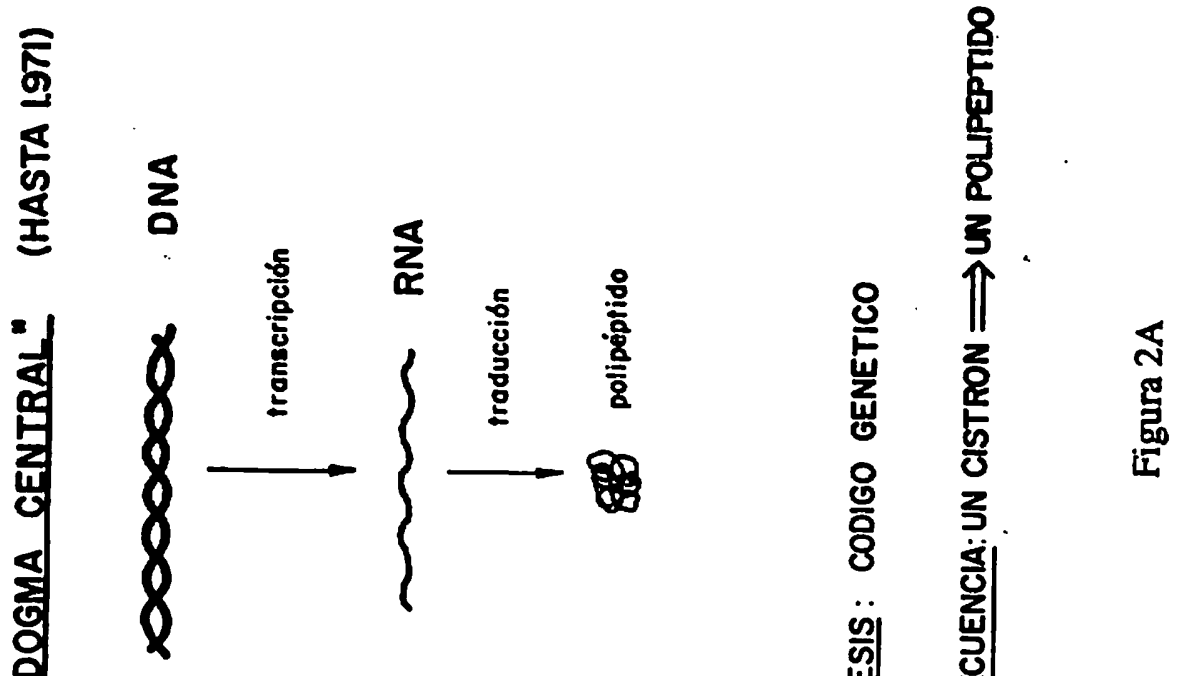
Afortunadamente, el "dogma" duró tan sólo el tiempo necesario para descubrir que el material genético de muchos virus es RNA, el cual se copia en DNA (transcripción inversa; Figura 2B).

Finalmente, nuevas piezas se añaden al tablero al descubrirse y utilizarse una serie de enzimas que actían sobre el DNA: enzimas de restricción, capaces de reconocer y cortar el DNA en una secuencia determinada; metilasas, modificadoras del DNA y DNA ligasas, capaces de sellar extremos de moléculas de DNA. A la utilidad de éstos, se añade la de otros enzimas ya conocidos: los enzimas de reparación (DNA polimerasas de tipo I) y algunas desoxirribonucleasas (DNasas) cuya acción controlada permitirá una manipulación final del DNA.

\section{Tecnología del DNA recombinante}

El esquema conceptual de la construcción de un DNA recombinante es relativamente simple y se basa en la posibilidad de cortar DNA en fragmentos discretos (digestión con enzimas de restricción), unir sus extremos (ligación), introducirlos en un organismo (transformación) y rescatar finalmente las moléculas generadas. La realización experimental, en un ejemplo simple, requiere una serie de condiciones que quedan esquematizadas en la Figura 3. En primer lugar, el DNA que se desea clonar ("DNA pasajero") se digiere con un enzima de restricción que genere extremos autocomplementarios (extremos cohesivos) o extremos romos. Este DNA se liga a un DNA vector digerido con el mismo enzima de restricción o con otro que genere extremos compatibles. El DNA vector debe ser capaz de replicarse en el organismo huésped elegido y es deseable que posea algún carácter genético seleccionable (habitualmente, una resistencia a un antibiótico). La mezcla de ligación se utiliza para transformar al organismo huésped (se suele emplear la bacteria Escherichia coli). Las células del huésped transformadas con el DNA recombinante se pueden seleccionar en un medio de cultivo sólido para, finalmente, extraer un DNA, analizarlo y comprobar que contienen el DNA recombinante deseado. Esta estrategia de clonaje es la clásica y no se emplea demasiado en la actualidad. El esquema se ha modificado enormemente, en función del tipo de DNA que se desea clonar, de la selección aplicada, del organismo huésped, etc. ... Existe la tecnologfa para convertir el sitio de reconocimiento de un enzima de restricción por otro diferente, se han diseffado vectores especificos para ciertos clonajes, vectores para expresar en grandes cantidades el producto del gen clonado, etc. Se han desarrollado métodos y vectores para introducir, y mantener de forma estable, DNA recombinante en células vegetales y animales. De esta manera, características típicas de un ser vivo pueden ser transferidas y expresadas de forma hereditaria en otros seres vivos. En cualquier caso, la elección del organismo huésped depende del gen que se desea clonar y de la evaluación de las ventajas e inconvenientes del organismo elegido (Tabla 1). Uno de los criterios puede ser el económico, puesto que hiperproducir un producto en una bacteria (alrededor de un billón de células bacterianas en dos litros de cultivo) puede ser mucho menos 


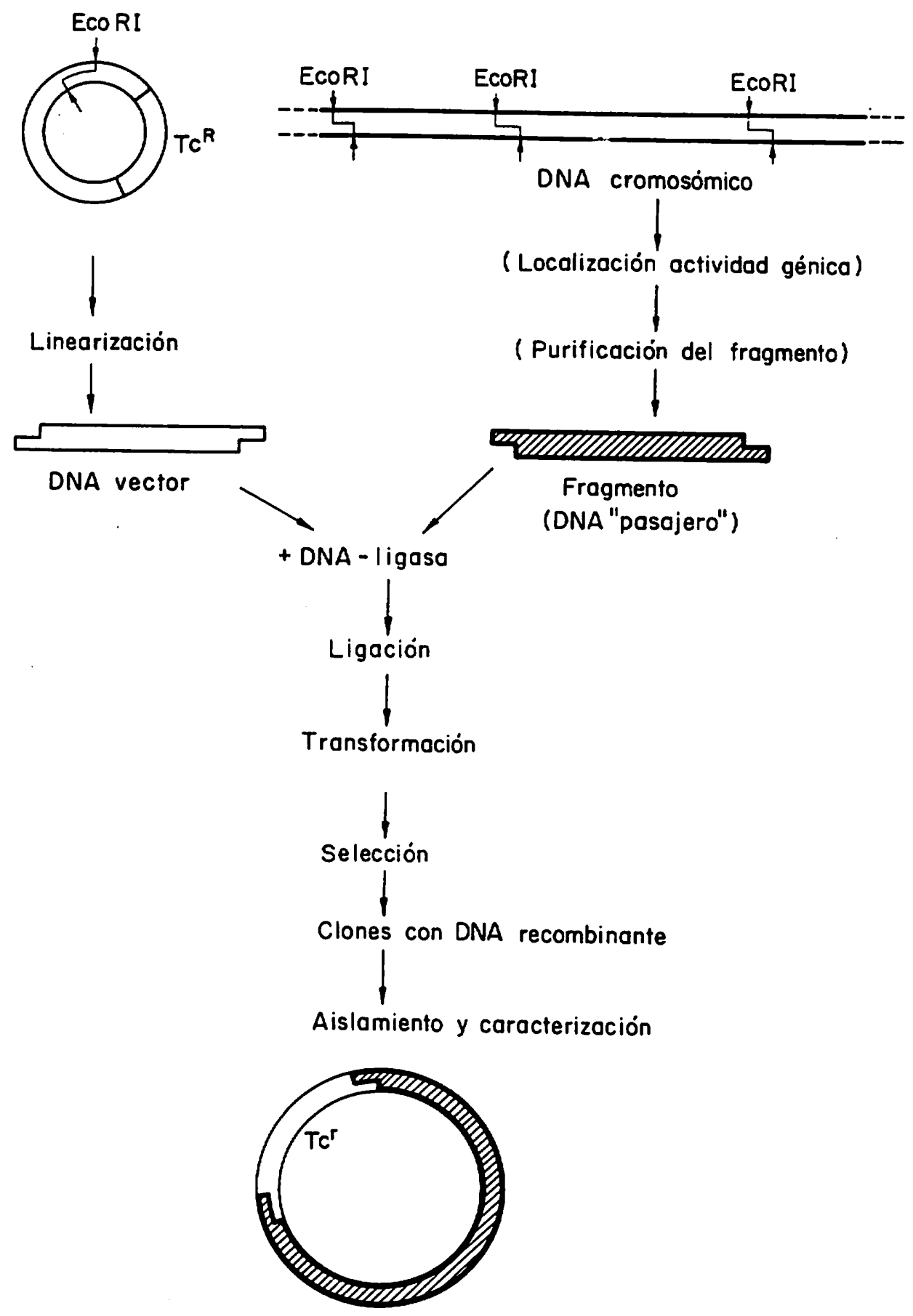

Figura 3 
costoso que el hacerlo en otros huéspedes. Además, la aplicación de las reacciones específicas para la caracterización de las bases del DNA (desarrolladas en las décadas 50-60), ha permitido la puesta a punto de procedimientos para determinar el orden de estas bases en un determinado gen (secuenciación del DNA). Ello, unido a la automatización de estas técnicas y la transferencia de resultados a supercomputadores, ha permitido el planteamiento de proyectos tan ambiciosos como la secuenciación de todo el genoma humano.

Tabla 1: Algunos microorganismos de interés en Biotecnología

\begin{tabular}{|c|c|c|c|c|}
\hline Microorganismo & $\begin{array}{l}10 \text { Productos } \\
\text { de interés }\end{array}$ & Aplicación & Ventajas & Inconvenientes \\
\hline E. Coli & & & $\begin{array}{l}\text { bacteria de } \\
\text { elección para } \\
\text { clonajes }\end{array}$ & $\begin{array}{l}\text { Síntesis de } \\
\text { lipopolisacáridos }\end{array}$ \\
\hline Pseudomonas & $\begin{array}{l}\text { Polisacáridos } \\
\text { Proteasas }\end{array}$ & $\begin{array}{l}\text { Alimentación } \\
\text { Peletería } \\
\text { Ind. Químicas }\end{array}$ & $\begin{array}{l}\text { Buen conocimiento } \\
\text { genético y } \\
\text { bioquímico }\end{array}$ & $\begin{array}{l}\text { Baja eficiencia } \\
\text { de expresión }\end{array}$ \\
\hline Bacillus & $\begin{array}{l}\text { Proteasas } \\
\text { Amilasas } \\
\text { Celulosas }\end{array}$ & $\begin{array}{l}\text { Ind. Químicas } \\
\text { Ind. Textil } \\
\text { Ind. Papeleras } \\
\text { Antibióticos }\end{array}$ & $\begin{array}{l}\text { Buen conocimiento. } \\
\text { Secreción. } \\
\text { Fermentación } \\
\text { Ind. Farmacéuticas } \\
\text { Detergentes } \\
\text { Bioconversión }\end{array}$ & $\begin{array}{l}\text { Alto contenido } \\
\text { en proteasas. } \\
\text { Alto contenido } \\
\text { en DNasas. }\end{array}$ \\
\hline Streptomyces & $\begin{array}{l}\text { Antibioticos } \\
\text { Celulosas } \\
\text { Proteasas }\end{array}$ & $\begin{array}{l}\text { Ind. Farmacéutic } \\
\text { Alimentación } \\
\text { Ind. Textil }\end{array}$ & $\begin{array}{l}\text { Experiencia } \\
\text { en fermentación. } \\
\text { Secreción }\end{array}$ & $\begin{array}{l}\text { Poco conocimiento } \\
\text { genético. Mala } \\
\text { expresión } \\
\text { heteróloga }\end{array}$ \\
\hline $\begin{array}{l}\text { Hongos } \\
\text { filamentosos }\end{array}$ & $\begin{array}{l}\text { Antibióticos } \\
\text { Celulasas } \\
\text { Quitinasas }\end{array}$ & $\begin{array}{l}\text { Ind. Farmacéutic } \\
\text { Ind. Papeleras } \\
\text { Bioconversión }\end{array}$ & $\begin{array}{l}\text { sExperiencia en } \\
\text { fermentación. } \\
\text { Manipulación } \\
\text { simple }\end{array}$ & $\begin{array}{l}\text { Poco conocimiento } \\
\text { genético. Pocos } \\
\text { vectores de } \\
\text { clonaje }\end{array}$ \\
\hline Levaduras & $\begin{array}{l}\text { Fermentaciones } \\
\text { alcohólicas } \\
\text { Vitaminas. }\end{array}$ & & $\begin{array}{l}\text { Experiencia } \\
\text { en fermentaciones. } \\
\text { Alto interés para } \\
\text { expresión génica }\end{array}$ & $\begin{array}{l}\text { Expresión } \\
\text { heteróloga } \\
\text { pobre. }\end{array}$ \\
\hline
\end{tabular}


4. Utilización de productos de interés en biotecnología: economía, ciencia y sociedad

Esta vez, en esencia, la tecnología empleada por la Ingenierfa Genética para el clonaje de genes. Algunos ejemplos de logros conseguidos podrán ilustrar el potencial que nos presenta. Así, el gen de la insulina humana se clono en $E$. coli y su producto, purificado de cultivos de estas bacterias está comercialmente disponible. Lógicamente, el coste del producto puede ser mínimo en un futuro próximo. El mismo criterio se ha aplicado para la producción del interferón humano, para la hormona de crecimiento, tanto humana como de algunos animales de interés, para el desarrollo de vacunas, etc. Se han clonado y transferido a plantas, genes de bacterias cuyos productos hacen a la planta resistente a infecciones por algunos insectos. Otros genes bacterianos se han transferido a plantas de interés horto-frutícola para protegerlas frente a heladas, etc. El porvenir se presenta, pues, lleno de posibilidades tendentes a la mejora de la salud humana y animal y a una mayor calidad de vida.

Sin embargo, no deseo dar una tonalidad teñida tan sólo de color rosa a mi exposición. Indudablemente, los logros derivados de la Biotecnología son y serán grandes. Pero, indudablemente también, conviene analizar quiénes van a ser sus beneficiarios directos. En primer lugar, la tecnología de la Ingenierfa Genética está siendo desarrollada principalmente en los USA, Japón y (muy por detrás) Europa. Es, por ejemplo, muy sintomático, la preocupación existente en los USA por la salida de esta tecnología a otros países, especialmente a la URSS y al Japón. De hecho, se está planteando la posibilidad de restringir la venta (fuera de los USA) de equipo biotecnológico. En segundo lugar, la mayorfa de la investigación se desarrolla, total o parcialmente, en industrias pequeñas o en grandes empresas multinacionales. La investigación académica (Universidades y Centros Públicos de Investigación) se dirige a aspectos más básicos y los posibles resultados aplicados se patentan o venden a las industrias. Esta dinámica implica que los beneficiarios más directos de la aplicación de la Biotecnología van a ser estas industrias y, de últimas, los países más desarrollados. Será previsible que las diferencias actuales entre países se vean acentuadas en el futuro, a menos que exista un planteamiento nuevo de las relaciones entre países. Como no conozco ningún ejemplo histórico de ello, hago énfasis en lo de la novedad.

\section{Terapia génica y armas biológicas: ciencia y ética}

Para finalizar, deseo hacer algunas reflexiones, que no juicios, sobre el posible futuro (rosa y negro) de la tecnología del DNA recombinante. Quiero destacar que la mayorfa de los gobiemos exigen que la experimentación se realice bajo unas normas de seguridad que dependen del grado de riesgo potencial que dicha experimentación entrañe. Asf, se han establecido cuatro tipos de restricciones, que van desde las simple 
medidas de higiene y descontaminación (condiciones P1 o P2) hasta la necesidad de realizar la experimentación en laboratorios bajo presión negativa (condiciones $\mathrm{P} 3$ ) 0 absolutamente aislados (por ejemplo, bajo tierra o lagos, en las condiciones P4). La regulación de las pruebas de campo sobre liberación (aún en condiciones controladas) de microorganismos genéticamente manipulados es muy estricta, quizás con demasiado énfasis en potenciales peligros que, muchas veces son mínimos o inexistentes. Es importante dejar esto claro, para que la sociedad sea consciente de los esfuerzos de políticos y cientificos para establecer medidas de control en la experimentación biotecnológica.

He mencionado antes que se pueden insertar y expresar genes, de forma estable, en organismos superiores (animales y plantas). Ejemplos de animales transgénicos, en los que se han insertado varias copias del gen de la hormona de crecimiento y que muestran un tamaño dos o tres veces superior al de sus hermanos han sido noticia en la prensa diaria. Estos resultados han abierto bastantes especulaciones para desarrollar una terapia génica, cuyo ejemplo más evidente sería e de la inserción del gen de la insulina en enfermos diabéticos, eliminando así la carencia de esta hormona. Otros ejemplos se podrían describir como factibles para el tratamiento de muchas de las enfermedades genéticas conocidas: enanismo, talasemia, fenilcetonuria, distrofias musculares, etc. Esta disponibilidad tecnológica, indudablemente al alcance de la mano, plantea la cuestión ética de dónde poner los límites a la Biología. Creo que es una cuestión absolutamente opinable y que será solamente una sociedad culta, libre e informada la que tendrá que decidirlo. La misma decisión afecta a la posibilidad de desarrollo de armas biológicas nuevas, cuyo control es más que dudoso pero que ha planteado un serio debate en la comunidad cientifica norteamericana. Es actualmente posible el desarrollo de nuevas bacterias patógenas que tengan múltiples antibioticoresistencias, el clonaje e hiperproducción de genes que codifican para toxinas microbianas, la producción de virus recombinantes patógenos para el hombre y otros horrores que desconozco. El planteamiento de que gran parte de esta investigación puede tener carácter defensivo es cuestionable, pero no banal. Es, no obstante, esperanzador que un grupo de más de 500 científicos de la USA hayan firmado un manifiesto en contra de este tipo de investigación. Es posible, pues, mantener la esperanza de que, por primera vez, el planteamiento nuevo que mencioné antes sea una realidad. 